\title{
HIV voluntary counseling and testing practices among military personnel and civilian residents in a military cantonment in southeastern Nigeria
}

This article was published in the following Dove Press journal:

HIVIAIDS - Research and Palliative Care

12 October 2011

Number of times this article has been viewed

\section{BN Azuogu \\ LU Ogbonnaya \\ CN Alo}

Communicable Diseases Control Research Centre, Department of Community Medicine, Ebonyi State University Teaching Hospital, Abakaliki, Nigeria
Correspondence: LU Ogbonnaya Communicable Diseases Control Research Centre, Department of Community Medicine, Ebonyi State University, Teaching Hospital,

Abakaliki, Nigeria

Tel +234 8034502950

Email uluogbonnaya@yahoo.com
Background: Voluntary counseling and testing (VCT) services are expected to lower rates of HIV transmission through a reduction in high-risk sexual behavior and through improved access to medical treatment, care, and support. However, increasing access to and uptake of VCT, especially among groups at high risk for HIV infection, has remained a major challenge in Africa.

Purpose: The study was undertaken to determine the uptake of VCT (measured by whether study participants had ever received an HIV test) and the factors influencing this practice among military and civilian residents of a military cantonment in Abakaliki, southeastern Nigeria.

Methods: A cross-sectional descriptive survey of all cantonment residents aged between 20 and 64 years was conducted. A multistage sampling technique was used to establish the sample size; data were collected from 350 military and civilian cantonment residents using a pretested questionnaire. Data were analyzed using SPSS software (v 16.0; SPSS Inc, Chicago, IL) and the significance of any association was tested at $P<0.05$ using the chi-square statistic.

Results: One hundred and forty-five (41.4\%) respondents reported having ever been tested for HIV; however, only 44 (12.6\%) respondents had received the test between 4 and 12 months prior to the survey period. Some of the significant factors that positively influenced uptake of VCT were awareness of VCT $(P<0.001)$, education level $(P<0.006)$, and knowledge of antiretroviral therapy benefits $(P<0.01)$.

Conclusion: The uptake of VCT by the residents of the cantonment was low. The establishment of VCT services in the cantonment is urgently recommended, together with the targeting of high-risk population groups in HIV/AIDS and VCT information dissemination efforts.

Keywords: VCT uptake, HIV test, most-at-risk population (MARP), people living with HIV/ AIDS (PLWHAs)

\section{Introduction}

Voluntary counseling and testing (VCT) is the process by which an individual undergoes counseling to enable him or her to make informed choices about being tested for HIV, adopting healthy sexual behavior, and improving quality of life if he or she tests positive for HIV. The voluntary nature of VCT is one of its underlying principles. ${ }^{1}$

Counseling for HIV testing consists of pretest, post-test, and follow-up counseling. Pretest counseling gives an individual or a couple opportunities to explore and analyze their risk status and consider being tested for HIV. ${ }^{2}$ Post-test counseling supports people in understanding their test result, whether positive or negative. Follow-up counseling supports clients in coping with issues that may arise as a result of knowing their HIV status and is relevant for clients that test either positive or negative. ${ }^{2}$ 
HIV testing involves analysis of blood or body fluids for the presence of antigens or antibodies produced in response to HIV. ${ }^{3}$ Simple rapid tests can be used and will usually give results in less than 30 minutes. They are easy to perform and do not require special equipment or highly trained staff. ${ }^{1}$

VCT serves as an entry point to HIV/AIDS prevention, care, and support. ${ }^{4}$ There are several models of VCT service delivery, each with its particular benefits and challenges. These models include freestanding services, integrated models (within primary health care services, hospitals, and clinics), social marketing models, private sector models, mobile/outreach models, and home testing. ${ }^{2}$

Although sub-Saharan Africa has just over $10 \%$ of the world's population, it is home to more than $60 \%$ of all people living with HIV/AIDS (PLWHAs). ${ }^{5}$ Less than $10 \%$ of these people are aware they are infected, mainly because of limited availability of, access to, and uptake of VCT for HIV/AIDS. ${ }^{5}$ A number of surveys conducted in 25 African countries since 2003 show a median of $9 \%$ of men and $7 \%$ of women reported having ever had an HIV test. ${ }^{6}$

In many African countries, the uniformed services report an HIV prevalence rate higher than the national average. For example, in Uganda the 1996 HIV prevalence rate of $27 \%$ among the military was more than three times the 1999 national prevalence rate of $8.3 \% .^{7}$ South Africa reported a prevalence rate of $60 \%-70 \%$ in the armed forces, compared with $20.1 \%$ in the adult population. ${ }^{8}$ In 1993 , Cameroon reported an HIV prevalence rate of $6.2 \%$ in the military, compared with $2 \%$ in the general population. ${ }^{9}$ HIV prevalence figures for Nigeria's 150,000-strong armed forces are unavailable in the public domain since force-wide HIV testing has not been conducted. Preliminary results from an ongoing study funded by the US Naval Health Research Center found a 15\% HIV seroprevalence rate among Nigerian soldiers on active duty. Similarly, the infection rate for sexually transmitted infections (STIs) is commonly two to five times higher in the military than in the civilian population. ${ }^{10}$

Some factors that have been expressed as barriers to VCT include (1) lack of accurate information about sexual health and modes of HIV transmission; (2) fear of rejection or stigma if HIV test result is positive; (3) long distances to travel to reach VCT centers; (4) lack of trained counselors; and (5) lack of space to ensure privacy and confidentiality. ${ }^{2,11,12}$ The lack of accurate information about sexual health has meant that there are many myths and misconceptions about sex and HIV; these myths and misconceptions contribute to increasing transmission rates and to stigma and discrimination toward PLWHAs. In 2005, the Joint United Nations
Programme on HIV/AIDS estimated that in Nigeria only $18 \%$ of women and $21 \%$ of men between the ages of 15 and 24 years correctly identify ways to prevent HIV. ${ }^{13}$

Results from a knowledge, attitude, and practice survey of the Nigerian armed forces conducted in 2001 showed that only $40 \%$ of the respondents had a good knowledge of HIV/AIDS transmission and prevention, while $25 \%$ of those surveyed had a poor knowledge of HIV/AIDS. Forty-one percent felt they faced no risk of contracting HIV, while $22 \%$ felt they carried only a small risk despite high-risk exposures. Only $40 \%$ of the respondents had been tested for HIV, 35\% of whom had taken the test voluntarily, and $15.3 \%$ reported having had at least two sexual partners within the previous year. According to the survey, women constitute $6 \%-10 \%$ of the military in Nigeria. ${ }^{14}$

An assessment of the perception and predisposing factors of HIV/AIDS among 400 soldiers in Ilorin, northern-central Nigeria, revealed that over $75 \%$ had a high knowledge of HIV/AIDS. ${ }^{15}$ Approximately half (51.1\%) believed that they were not at risk of contracting HIV infection, while approximately $79 \%$ were willing to undergo voluntary HIV screening. The study found the rate of consistent condom use was low. In another study, in 2003, an intervieweradministered survey of 209 Nigerian military and affiliated personnel presenting for annual physical and other medical examinations in a military hospital in Jos, northern-central Nigeria, was performed. The study revealed that $93.8 \%$ of unmarried participants reported sex within the previous 6 months, while $34.0 \%$ reported inconsistent condom use (never/sometimes). ${ }^{16}$

Access to and uptake of VCT has remained a major challenge in Africa compared with other regions of the world. In the United States, for example, a survey in 2006 revealed that, overall, $37.8 \%$ of women and $33.7 \%$ of men reported having ever been tested for HIV. ${ }^{17}$ However, in most parts of sub-Saharan Africa, fewer than one in ten people know their HIV status. The 2007 National HIV/AIDS and Reproductive Health Survey in Nigeria showed that $56 \%$ of men and $49 \%$ of women had knowledge of where to receive an HIV test. Level of education positively correlated with knowledge of where to seek an HIV test, as those with a higher education had a higher knowledge of VCT (77\%) than those who had not been to school $(31 \%){ }^{18}$

Factors that limit people's access to traditional VCT services include (1) stigma; (2) fear of receiving an HIVpositive result; (3) lack of confidentiality; (4) long travel distances to VCT centers; and (5) long delays in the return of HIV test results. ${ }^{12}$ This is reflected by the findings of a study 
among 240 pregnant women in Awka, southeastern Nigeria, where $69 \%$ of the $13 \%$ who refused VCT attributed their refusal to the social and cultural stigmatization associated with an HIV-positive test result. ${ }^{19}$

VCT has been recognized as a key component of, and entry point to, effective HIV prevention and care; knowledge of where the services can be obtained is essential. ${ }^{20}$ Therefore, the purpose of the current study was to determine the factors affecting the uptake of VCT services by military personnel and their affiliated civilian population in Nkwegu Military Cantonment in Abakaliki, southeastern Nigeria. This was to serve as a baseline measurement for a larger intervention study aiming to determine the impact of community mobilization activities on the utilization of VCT services in the military cantonment.

The Nkwegu Military Cantonment was established in 1968 during the Nigerian civil war and currently has a total population of approximately 1550 persons, comprising 250 soldiers and 1300 civilians. The soldiers belong to four corps divisions: Engineering, Records, Command, and the Petroleum Oil and Logistic Reserve. The civilians are predominantly schoolteachers, national youth service corps (NYSC) members, civil servants, and businessmen and women. Both the soldiers and the civilians are quartered in well-demarcated and orderly numbered blocks of approximately 1340 flats. There are two secondary schools, three primary schools, a church, a mosque, a health facility (the medical reception station [MRS]), and a mammy market inside the cantonment.

This cantonment is a unit of the Eighty-Second Division of the Nigerian Army, with its headquarters in Enugu, Enugu State, southeastern Nigeria. The cantonment has a senior military officer in the rank of colonel as its commander and the commander reports to the general officer commanding the Eighty-Second Division.

\section{Methodology}

\section{Sample size and sampling technique}

The study population comprised all people between the age of 15 and 64 years who were officially residing in Nkwegu Military Cantonment. This was a cross-sectional descriptive study. Using a multistage sampling technique, a sample size of 350 military and civilian residents of the cantonment was established, comprising 190 military and 160 civilian residents. The first stage of the sampling procedure was to stratify the population into military and civilians.

For the military subsample, all the personnel in the cantonment were intended to be included in the study. Because the military personnel are regularly involved in outside peacekeeping operations and other internal peacekeeping duties, and because of military policy to not disclose to outsiders the actual number of soldiers living in the cantonment at any point for security purposes, it was not possible at the planning stage to know the actual number of people who would make up the subsample. The authors were informed the number of soldiers might be 150 or more. The authors estimated they would meet approximately 160 soldiers in the cantonment during the study and it was decided that this number would be matched with an equal number of civilians. However, during the recruitment process proper, 190 soldiers were met and all were recruited into the study.

For the civilian subsample, the authors used a multistage sampling technique to recruit 160 civilian residents into the study. In the first stage, the civilians were stratified into four major occupational groups (schoolteachers, NYSC members, traders/artisans, and others). In the second stage of the sampling procedure, a systematic sampling method was used to recruit 40 civilians from each occupational stratum, using the nominal roll of their house allocation register as the sampling frame and a sampling fraction of three. A minimum of three repeat calls were made to each person sampled at different times of the day to ensure that they were met and interviewed. After the third repeat call, those who were not met were replaced through another round of random sampling.

\section{Data collection}

Data were collected using a pretested, structured, intervieweradministered questionnaire. Information obtained included the socio-demographic profile, knowledge of HIV/AIDS, sexual behavior pertinent to the transmission of HIV/AIDS, awareness of VCT, and HIV-1 testing behavior of the respondents. Five research assistants who were trained in the questionnaire format and interview administration for the purpose of this study collected the data.

\section{Data analysis}

Data were analyzed using SPSS software (v 16.0; SPSS Inc, Chicago, IL). Frequency distributions of relevant variables were presented and relevant means and percentages were calculated. A composite score on knowledge of VCT and HIV/AIDS was collected using responses to a set of six and ten questions, respectively; each correct response was allotted one point and the total score from correct responses was used to grade knowledge ranging from "excellent" to "very poor." The scores for VCT knowledge were as 
follows: $6 / 6=$ excellent; $4-5 / 6=$ good; $3 / 6=$ fair; $2 / 6=$ poor; $0-1 / 6=$ very poor. The scores for HIV/AIDS knowledge were as follows: $9-10 / 10=$ excellent; $7-8 / 10=$ good; $5-6 / 10=$ fair; $3-4 / 10=$ poor; $0-2 / 10=$ very poor. Bivariate analysis was performed to assess the associations between HIV testing and socio-demographic characteristics and other variables. The socio-demographic characteristics, knowledge of HIV/AIDS, sexual behavior, knowledge of VCT, and HIV-1 testing behavior of the military personnel and their civilian counterparts were compared. The significance of any association was tested using the chi-square statistic for categorical variables. Statistical significance was set at $P<0.05$.

\section{Ethical clearance}

The ethical clearance for this study was obtained from the research ethics committee of the Ebonyi State University Teaching Hospital (EBSUTH), Abakaliki. Permission for the study was further obtained from the commander of the Nkwegu Military Cantonment. Each respondent was required to sign a written informed consent document after the purposes and procedure of the study had been explained to them. They were assured that they were free at any stage of the study to withdraw their consent without penalty.

\section{Results}

\section{Sociodemographic characteristics of the respondents}

The sociodemographic characteristics showed an age range of 20-62 years. Generally, the mean age of the study population was $40.49 \pm 8.9$ years. The mean age of the military personnel only was $41.1 \pm 7.2$ years and the mean age of the civilian respondents only was $39.8 \pm 10.5$ years. The difference between these two means was not statistically significant $(t=1.31 ; \mathrm{df}=348 ; P>0.05)$. However, the military and civilian populations differed significantly on the age group distribution. The 20-29 years age group comprised only $6.3 \%$ of the military, compared with $26.3 \%$ of the civilian respondents. Similarly, the 30-39 years age group comprised $42.1 \%$ of the military, compared with only $23.8 \%$ of the civilian respondents. The difference in these proportions is statistically significant $\left(\chi^{2}=34.7\right.$; degree of freedom $[\mathrm{df}]=3$; $P<0.0001)$ (see Table 1).

Most respondents (219 [62.6\%]) were married and living with their spouses. There was a statistically significant difference in marital status between the military and the civilian populations in the cantonment. The study showed $26.3 \%$ of the married military personnel were not living with a spouse, compared with $8.2 \%$ of the civilians, and $8.4 \%$ of

Table I Sociodemographic characteristics of respondents

\begin{tabular}{|c|c|c|c|}
\hline Variable & Military $(n=190[\%])$ & Civilian $(n=160[\%])$ & $\chi^{2}$ and $P$-value \\
\hline \multicolumn{4}{|l|}{ Sex } \\
\hline Male & $167(89.7)$ & $53(33.1)$ & \multirow[t]{2}{*}{$\chi^{2}=111.6 ; P<0.0001$} \\
\hline Female & $23(10.3)$ & $107(66.1)$ & \\
\hline \multicolumn{4}{|l|}{ Age (years) } \\
\hline $\begin{array}{l}\text { Difference of mean age between military } \\
\text { personnel and civilians }\end{array}$ & $4 I .1 \pm 7.2$ & $39.8 \pm 10.5$ & $t=\mathrm{I} .3 \mathrm{I} ; \mathrm{df}=348 ; P>0.05$ \\
\hline \multicolumn{4}{|l|}{ Distribution } \\
\hline $20-29$ & $12(6.3)$ & $42(26.3)$ & \multirow[t]{4}{*}{$\chi^{2}=34.7 ; \mathrm{df}=3 ; P<0.0001$} \\
\hline $30-39$ & $80(42.1)$ & $38(23.8)$ & \\
\hline $40-49$ & $71(37.4)$ & $47(29.4)$ & \\
\hline$\geq 50$ & $27(14.2)$ & $33(20.6)$ & \\
\hline \multicolumn{4}{|l|}{ Marital status } \\
\hline Married, living with spouse & $124(65.3)$ & $95(59.4)$ & \multirow[t]{3}{*}{$\chi^{2}=42.37 ; \mathrm{df}=2 ; P<0.000 \mathrm{I}$} \\
\hline Married, not living with spouse & $50(26.3)$ & $13(8.2)$ & \\
\hline Other (single, separated, divorced, widowed) & $16(8.4)$ & $52(32.5)$ & \\
\hline \multicolumn{4}{|l|}{ Education level } \\
\hline$\leq$ Primary & $14(7.4)$ & $14(8.7)$ & \multirow[t]{4}{*}{$\chi^{2}=73.3 ; \mathrm{df}=3 ; P<0.0001$} \\
\hline Secondary & $93(48.9)$ & $40(25)$ & \\
\hline Postsecondary & $53(27.9)$ & $14(8.8)$ & \\
\hline Tertiary & $30(15.8)$ & $92(57.5)$ & \\
\hline \multicolumn{4}{|l|}{ Tribe } \\
\hline Igbo & $68(35.8)$ & $93(58.1)$ & \multirow[t]{4}{*}{$\chi^{2}=27.9 ; \mathrm{df}=3 ; P<0.000 \mathrm{I}$} \\
\hline Hausa/Fulani & $42(22.1)$ & $8(5.0)$ & \\
\hline Yoruba & $18(9.5)$ & $12(7.5)$ & \\
\hline Other & $62(32.6)$ & $47(29.3)$ & \\
\hline
\end{tabular}

Abbreviation: df, degree of freedom. 
the military were single, separated, divorced, or widowed, compared with $32.5 \%$ of the civilians. These differences were highly statistically significant $\left(\chi^{2}=42.37\right.$; df $=2$; $P<0.0001$ ) (see Table 1).

The study population was largely literate, as 221 (92\%) of them had a secondary education or higher, and the majority (161 [46\%]) of respondents were of the Igbo tribe. There were also significant differences between the military and the civilians in level of education $\left(\chi^{2}=73.3 ; \mathrm{df}=3 ; P<0.0001\right)$ and ethnic distribution $\left(\chi^{2}=27.9\right.$; df $\left.=3 ; P<0.0001\right)$ (see Table 1).

\section{Knowledge of HIVIAIDS and the means of its prevention}

Generally, with regard to knowledge of HIV/AIDS, 126 (36\%) of the respondents had a good to excellent knowledge, $98(28 \%)$ had a fair knowledge, and another 126 (36\%) had a very poor to poor knowledge. However, while a good to excellent knowledge was found in $27.3 \%$ of the military, the percentage of civilians with a good to excellent knowledge was higher (approximately 46.3\%). The two subpopulations differed significantly in their knowledge of HIV/AIDS $\left(\chi^{2}=20.2 ; \mathrm{df}=2 ; P<0.001\right)$ (see Table 2$)$.

With regard to knowledge of the specific means of prevention of HIV transmission, the highest proportion of respondents (221 [63\%]) chose being faithful to one uninfected partner as a means of prevention, while the lowest proportion (112 [32\%]) chose avoiding indiscriminate use of drug injections as a means of prevention. When the military and civilian groups were compared, their knowledge of the different specific measures of knowledge tested in this study were similar except in the knowledge that sexual abstinence is a means of preventing HIV transmission; in this case, $72.5 \%$ of the civilians, compared with $48.4 \%$ of the military, knew that sexual abstinence is a means of preventing HIV transmission $\left(\chi^{2}=24.1 ; P<0.001\right)$ (see Table 2$)$.

\section{Sexual behavior of respondents pertinent to the transmission of HIV}

Some of the sexual behavior pertinent to the transmission of HIV inquired into in this study included having casual sex within the previous 3 months, having multiple sexual partners, and consistent condom use when having sexual intercourse with a casual partner. Results are shown in Table 3.

Generally, 94 (26.9\%) respondents had casual sex in the previous 3 months, out of which 74 (78.7\%) had two or more casual sexual partners. Only 43 (45.7\%) of those who had casual sex consistently used condoms, while 47 (50.1\%) inconsistently used condoms and 4 (4.2\%) never used condoms. The reasons proffered by those who either inconsistently or never used condoms during casual sex range from being unable to always afford the cost of condoms by $5.9 \%$ of the respondents to reduction of sexual satisfaction by $90.2 \%$ of respondents (see Table 3 ).

When the military and civilian populations were compared, it was seen that a higher proportion of the military $(32.1 \%)$ than the civilian $(20.6 \%)$ population had had casual sex in the previous 3 months $\left(\chi^{2}=5.83 ; P<0.01\right)$. However, there was no difference in the number of casual sexual partners or in condom use between these two groups. However, regarding the reason given for not using condoms during casual sex, a higher proportion of the military than the civilian population did not use condoms for the following reasons: (1) reduces sexual satisfaction (odds ratio $[\mathrm{OR}]=2.32)$; (2) delays orgasm $(\mathrm{OR}=3.74)$; (3) religion prohibits use $(\mathrm{OR}=2.46)$; and $(4)$ does not prevent STIs including HIV $(\mathrm{OR}=3.44)$. However, there was no

Table 2 Knowledge of HIVIAIDS and the means of its prevention

\begin{tabular}{|c|c|c|c|}
\hline Variable & Military (n = I90 [\%]) & Civilian (n = $160[\%])$ & $\chi^{2}$ and $P$-value \\
\hline \multicolumn{4}{|l|}{ Knowledge of HIVIAIDS } \\
\hline Good to excellent knowledge & $52(27.3)$ & $74(46.3)$ & \multirow[t]{3}{*}{$\chi^{2}=20.2 ; \mathrm{df}=2 ; P<0.001$} \\
\hline Fair knowledge & $70(36.8)$ & $28(17.5)$ & \\
\hline Very poor to poor knowledge & $68(35.7)$ & $58(36.2)$ & \\
\hline \multicolumn{4}{|l|}{ Means for preventing HIV transmission } \\
\hline Being faithful to one uninfected partner & I I 8 (62.I) & $103(64.4)$ & $\chi^{2}=0.484 ; P>0.05$ \\
\hline Sexual abstinence & $92(48.4)$ & I I 6 (72.5) & $\chi^{2}=24.1 ; P<0.001$ \\
\hline Avoiding transfusion with unscreened blood & $107(56.3)$ & $95(59.4)$ & $\chi^{2}=0.33 ; P>0.05$ \\
\hline Avoiding injections with used syringes and needles & IOI (53.2) & $90(56.3)$ & $\chi^{2}=0.77 ; P>0.05$ \\
\hline Wearing gloves and other personal protective devices & $92(48.4)$ & $88(55.0)$ & $\chi^{2}=0.9 ; P>0.05$ \\
\hline Not sharing sharp objects & $89(46.8)$ & $67(41.9)$ & $\chi^{2}=2.31 ; P>0.05$ \\
\hline Consistent use of condoms during casual sexual intercourse & $88(46.3)$ & $63(39.4)$ & $\chi^{2}=0.69 ; P>0.05$ \\
\hline Treating STIs promptly & $67(35.3)$ & $63(39.4)$ & $\chi^{2}=0.63 ; P>0.05$ \\
\hline Avoiding indiscriminate use of drug injection & $55(28.9)$ & $57(35.6)$ & $\chi^{2}=1.78 ; P>0.05$ \\
\hline
\end{tabular}

Abbreviations: df, degree of freedom; STI, sexually transmitted infection.

Note: *Respondents ticked more than one option. 
Table 3 Sexual behavior of respondents

\begin{tabular}{|c|c|c|c|}
\hline Variable & Military $(n=190[\%])$ & Civilian (n = I60 [\%]) & $\chi^{2}$ and $P$-value \\
\hline \multicolumn{4}{|c|}{ Casual sex within the previous 3 months } \\
\hline Yes & $61(32.1)$ & $33(20.6)$ & \multirow[t]{2}{*}{$\chi^{2}=5.83 ; P<0.01$} \\
\hline No & $129(67.9)$ & $127(79.4)$ & \\
\hline \multicolumn{4}{|c|}{ Number of casual sexual partners within the past year } \\
\hline I & $106(55.8)$ & $94(58.8)$ & \multirow[t]{3}{*}{$\chi^{2}=0.53 ; P>0.05$} \\
\hline$\geq 2$ & $40(21.1)$ & $34(21.3)$ & \\
\hline No response & $44(23.2)$ & $32(20)$ & \\
\hline \multicolumn{4}{|c|}{ Condom used during casual sex } \\
\hline Yes & $83(43.7)$ & $73(45.6)$ & \multirow[t]{3}{*}{$\chi^{2}=0.23 ; P>0.05$} \\
\hline No & $70(36.8)$ & $55(34.4)$ & \\
\hline No response & $37(19.5)$ & $32(20)$ & \\
\hline \multicolumn{3}{|c|}{ Reasons for not using condom (military, $n=107$; civilian, $n=87$ ) } & OR \\
\hline Reduces sexual satisfaction & $31(28.9)$ & $13(14.9)$ & 2.32 \\
\hline Delays orgasm & $20(18.7)$ & $5(5.8)$ & 3.74 \\
\hline Religion prohibits use & $14(13.1)$ & $5(5.8)$ & 2.46 \\
\hline Does not prevent STIs & $8(7.5)$ & $2(2.3)$ & 3.44 \\
\hline Partner doesn't like it & $6(5.6)$ & $16(18.4)$ & 0.26 \\
\hline Other reason & $28(26.2)$ & $38(43.7)$ & 0.46 \\
\hline
\end{tabular}

Abbreviations: OR, odds ratio; STI, sexually transmitted infection.

difference between the military and the civilian populations in the proportion of those who did not use condoms because their partner did not like it or for some other unspecified reason (see Table 3 ).

\section{Respondents' perception of most-at-risk population groups}

A comparison was made between the military and the civilian respondents' perception of who constitute most-at-risk population (MARP) groups. Results show there was no difference in the proportion of the military and civilian respondents who identified long-distance truck drivers and homosexuals as MARP groups. However, a higher proportion of the civilians than the military perceived those with multiple sexual partners, members of the armed forces, intravenous drug users, and commercial sex workers as MARP groups (see Table 4). Only age and education level of the respondents influenced this perception (see Table 5).

\section{Awareness and knowledge of VCT}

Most of the respondents (193 [55.1\%]) had heard of VCT and $91(47.1 \%)$ respondents gave mass media as their most common source of information. Regarding knowledge of VCT, only $22(6.3 \%)$ of the respondents had an excellent knowledge of VCT, while 101 (28.9\%) had a good knowledge of VCT. One hundred and ninety $(54.3 \%)$ respondents had a poor to very poor knowledge (see Table 6).

Comparing the military and the civilian groups, there was no difference in the proportions of those who are aware of VCT. On the source of information, the military and the civilians differed only on public awareness events, as $28.4 \%$ of civilians, compared with $10.5 \%$ of the military, gave public awareness events as a source of VCT information $\left(\chi^{2}=10.33\right.$; $P<0.002)$. There was no significant difference between the

Table 4 Respondents' perception of most-at-risk population (MARP) groups

\begin{tabular}{|c|c|c|c|}
\hline $\begin{array}{l}\text { Occupation } \\
\text { of respondent }\end{array}$ & Yes & No & $\begin{array}{l}\chi^{2} \text { and } \\
P \text {-value }\end{array}$ \\
\hline & \multicolumn{2}{|c|}{ Long-distance drivers are } & a MARP \\
\hline Military & 49 & $|4|$ & $\chi^{2}=0.00$ \\
\hline \multirow[t]{2}{*}{ Civilian } & 41 & 119 & $P>0.05$ \\
\hline & \multicolumn{3}{|c|}{ Homosexuals are a MARP } \\
\hline Military & 82 & 108 & $\chi^{2}=2.46$ \\
\hline \multirow[t]{2}{*}{ Civilian } & 81 & 76 & $P>0.0 .05$ \\
\hline & \multicolumn{3}{|c|}{$\begin{array}{l}\text { Those with multiple sexual } \\
\text { partners are a MARP }\end{array}$} \\
\hline Military & 72 & 118 & $\chi^{2}=26.4 \mathrm{I}$ \\
\hline \multirow[t]{2}{*}{ Civilian } & 103 & 54 & $P<0.0001$ \\
\hline & \multicolumn{3}{|c|}{$\begin{array}{l}\text { Members of the armed } \\
\text { forces are a MARP }\end{array}$} \\
\hline Military & 52 & 138 & $\chi^{2}=11.18$ \\
\hline \multirow[t]{2}{*}{ Civilian } & 70 & 87 & $P<0.001$ \\
\hline & \multicolumn{3}{|c|}{$\begin{array}{l}\text { Intravenous drug users } \\
\text { are a MARP }\end{array}$} \\
\hline Military & 59 & $|3|$ & $\chi^{2}=6.38$ \\
\hline \multirow[t]{2}{*}{ Civilian } & 69 & 87 & $P<0.05$ \\
\hline & \multicolumn{3}{|c|}{$\begin{array}{l}\text { Commercial sex workers } \\
\text { are a MARP }\end{array}$} \\
\hline Military & 89 & 101 & $\chi^{2}=14.93$ \\
\hline Civilian & 106 & 51 & $P<0.001$ \\
\hline
\end{tabular}


Table 5 Influence of sociodemographic variables on perception of members of the armed forces as a most-at-risk population (MARP) group

\begin{tabular}{|c|c|c|c|}
\hline \multirow[t]{2}{*}{ Sociodemographic variable of respondent } & \multicolumn{2}{|c|}{ Members of the armed forces are a MARP } & \multirow[t]{2}{*}{$\chi^{2}$ and $P$-value } \\
\hline & Yes & No & \\
\hline \multicolumn{4}{|l|}{ Age group (years) } \\
\hline $20-29$ & 29 & 24 & \multirow[t]{4}{*}{$\chi^{2}=11.35 ; P<0.005$} \\
\hline $30-39$ & 34 & 84 & \\
\hline $40-49$ & 38 & 79 & \\
\hline$\geq 50$ & 21 & 38 & \\
\hline \multicolumn{4}{|l|}{ Sex } \\
\hline Male & 74 & 146 & \multirow{2}{*}{$\chi^{2}=1.11 ; P>0.05$} \\
\hline Female & 51 & 79 & \\
\hline \multicolumn{4}{|l|}{ Marital status } \\
\hline Married, living with spouse & 78 & 141 & \multirow[t]{3}{*}{$\chi^{2}=4.18 ; \mathrm{df}=2 ; P>0.05$} \\
\hline Married, not living with spouse & 17 & 46 & \\
\hline Other (single, divorced, widowed) & 30 & 38 & \\
\hline \multicolumn{4}{|l|}{ Education level } \\
\hline$\leq$ Primary & 8 & 20 & \multirow[t]{3}{*}{$\chi^{2}=8.1 ; \mathrm{df}=2 ; P<0.05$} \\
\hline Secondary & 36 & 97 & \\
\hline$>$ Secondary & 78 & 108 & \\
\hline
\end{tabular}

Abbreviation: $\mathrm{df}$, degree of freedom.

military and civilians in terms of their knowledge of VCT (see Table 6).

\section{Knowledge of where to access VCT services}

At the time of this study, VCT services were not available at the MRS in Nkwegu Military Cantonment. The only two facilities in Abakaliki where VCT services were available were EBSUTH and the Federal Medical Centre (FMC). The only other place military personnel could access VCT services was at the military hospital at the Eighty-Second Division headquarters in Enugu.

On average, only 105 (30\%) respondents correctly identified a facility from where VCT could be accessed

Table 6 Awareness, knowledge, and uptake of voluntary counseling and testing (VCT)

\begin{tabular}{|c|c|c|c|}
\hline Variable & Military $(n=190[\%])$ & Civilian $(n=160[\%])$ & $\begin{array}{l}\chi^{2} \text { and } P \text {-value and } \\
\text { Odds ratio values }\end{array}$ \\
\hline \multicolumn{4}{|l|}{ Awareness } \\
\hline Had heard of VCT before & $98(51.6)$ & $95(59.4)$ & $\chi^{2}=2.13 ; P>0.05$ \\
\hline Correctly identified where VCT can be accessed & $63(33.2)$ & $42(26.3)$ & $\chi^{2}=1.97 ; P>0.05$ \\
\hline \multicolumn{4}{|l|}{ Source of information* } \\
\hline Mass media & $51(52.0)$ & $40(42.1)$ & $\chi^{2}=1.91 ; P>0.05$ \\
\hline Family and friends & $25(25.5)$ & $18(18.9)$ & $\chi^{2}=1.20 ; P>0.05$ \\
\hline Public awareness events & $10(10.5)$ & $27(28.4)$ & $\chi^{2}=10.33 ; P<0.002$ \\
\hline Places of worship (church/mosque) & $2(2.0)$ & $4(4.2)$ & $\mathrm{OR}=0.48$ \\
\hline Other & II (II.2) & $7(7.4)$ & $\chi^{2}=0.85 ; P>0.05$ \\
\hline \multicolumn{4}{|l|}{ Knowledge of VCT } \\
\hline Excellent knowledge & $14(7.4)$ & $8(5.0)$ & \multirow[t]{5}{*}{$\chi^{2}=7.22 ; \mathrm{df}=4 ; P>0.05$} \\
\hline Good knowledge & $54(28.4)$ & $47(29.4)$ & \\
\hline Fair knowledge & $14(7.4)$ & $23(14.4)$ & \\
\hline Poor knowledge & $10(5.3)$ & $13(8.1)$ & \\
\hline Very poor knowledge & $98(51.6)$ & $69(43.1)$ & \\
\hline \multicolumn{4}{|l|}{ Ever accessed VCT services } \\
\hline Yes & 7I (37.4) & $73(45.6)$ & \multirow[t]{2}{*}{$\chi^{2}=2.45 ; P>0.05$} \\
\hline No & $119(62.6)$ & $87(54.4)$ & \\
\hline \multicolumn{4}{|l|}{ How long ago } \\
\hline$<4$ months ago & $5(2.6)$ & $8(5)$ & \multirow[t]{3}{*}{$\chi^{2}=0.56 ; \mathrm{df}=2 ; P>0.05$} \\
\hline Between 4 and 12 months ago & $22(11.6)$ & $22(13.8)$ & \\
\hline$>12$ months ago & $42(22.1)$ & $44(27.5)$ & \\
\hline
\end{tabular}

Abbreviations: $\mathrm{df}$, degree of freedom; OR, odds ratio.

Note: *Respondents ticked more than one option. 
(see Table 6). Specifically, for each facility, 102 (29.1\%), 110 (31.4\%), and 103 (29.4\%) of the respondents knew that VCT services were available from the FMC, EBSUTH, and Eighty-Second Division headquarters, respectively.

\section{Uptake of VCT services}

The number of respondents who had ever received an HIV test was used to measure the uptake of VCT. Generally, uptake of services was low among the respondents. Only $144(41.4 \%)$ respondents had ever received an HIV test. Of this number, only $13(3.7 \%)$ had received the test within the previous 4 months, $44(12.6 \%)$ had received the test between 4 and 12 months previously, while 88 , the majority, had received the test over 12 months previously (see Table 6). However, not all the HIV testing conformed to VCT standards. For example, only 44 (30.6\%) of those tests were voluntary, $76(52.8 \%)$ received pretest counseling, $65(45.1 \%)$ received post-test counseling, and $72(50 \%)$ paid for the test. However, 98 (68.1\%) of those who received the test also received their result.

There was no statistically significant difference between the military and the civilians in the proportion of those who have ever had an HIV-1 test done and the time the test was done.

\section{Factors that influenced the decision to receive an HIV test}

Result shows that age $\left(\chi^{2}=7.997\right.$; $\left.\mathrm{df}=3 ; P<0.046\right)$; education level $\left(\chi^{2}=14.550 ; \mathrm{df}=3 ; P<0.01\right)$; marital status $\left(\chi^{2}=14.173 ; \mathrm{df}=2 ; P<0.02\right)$; Type of family $\left(\chi^{2}=7.08\right.$; $\mathrm{df}=1 ; P<0.03)$; awareness of VCT $\left(\chi^{2}=81.843\right.$; df $=1$; $P<0.001)$, and knowledge that treatment with ART suppresses the replication of the virus, prolongs life, and improves the quality of life of PLWHAs $\left(\chi^{2}=9.116\right.$; $\mathrm{df}=2$; $\mathrm{P}<0.01)$ positively influenced the decision to receive an HIV test (see Table 7). The associations among having had casual sex in the previous 3 months, having many casual sexual partners, and condom use during casual sex did not positively influence the decision to receive an HIV test.

\section{Discussion}

The $41.4 \%$ HIV testing rate for the residents of this military cantonment was low. The rate for the military personnel, a MARP group, was even lower (37.4\%). This finding is comparable with the $40 \%$ uptake found in a similar study among military personnel in Lagos, southwestern Nigeria, in 2002. ${ }^{14}$ It is disturbing that despite the 7-year gap between the Lagos study and the current study, and
Table 7 Factors that influenced the decision to receive an HIV-I test

\begin{tabular}{|c|c|c|c|c|}
\hline \multirow[t]{2}{*}{ Characteristic } & \multicolumn{3}{|c|}{ Ever had an HIV test } & \multirow[t]{2}{*}{$\chi^{2}$ and $P$-value } \\
\hline & Yes & No & Total & \\
\hline \multicolumn{5}{|l|}{ Age (years) } \\
\hline $20-29$ & 29 & 25 & 54 & \multirow{4}{*}{$\begin{array}{l}\chi^{2}=7.997 ; \mathrm{df}=3 \\
P<0.05\end{array}$} \\
\hline $30-39$ & 50 & 68 & 118 & \\
\hline $40-49$ & 38 & 80 & 118 & \\
\hline$\geq 50$ & 27 & 32 & 59 & \\
\hline \multicolumn{5}{|l|}{ Education level } \\
\hline$\leq$ Primary & 6 & 22 & 28 & \multirow{4}{*}{$\begin{array}{l}\chi^{2}=14.550 ; \mathrm{df}=3 \\
P<0.01\end{array}$} \\
\hline Secondary & 44 & 89 & 133 & \\
\hline Postsecondary & 32 & 35 & 67 & \\
\hline Tertiary & 62 & 59 & $12 \mid$ & \\
\hline \multicolumn{5}{|l|}{ Marital status } \\
\hline Single & 36 & 22 & 58 & \multirow{2}{*}{$\begin{array}{l}\chi^{2}=14.173 ; \mathrm{df}=2 \\
P<0.02\end{array}$} \\
\hline $\begin{array}{l}\text { Married, living } \\
\text { with partner }\end{array}$ & 83 & 135 & 218 & \\
\hline \multicolumn{5}{|l|}{ with partner } \\
\hline \multicolumn{5}{|l|}{ Family type } \\
\hline Polygamous & 23 & 18 & 41 & $\chi^{2}=7.08: \mathrm{df}=\mathrm{I}$ \\
\hline Monogamous & 121 & 187 & 308 & $P<0.03$ \\
\hline \multicolumn{5}{|l|}{ Aware of VCT } \\
\hline Yes & 121 & 72 & 193 & $\chi^{2}=81.843 ; \mathrm{df}=\mathrm{I}$ \\
\hline No & 23 & 133 & 156 & $P<0.001$ \\
\hline \multicolumn{5}{|c|}{ Knowledge of ART benefits } \\
\hline Yes & 61 & 58 & 119 & $\chi^{2}=9.116 ; d f=2$ \\
\hline No & 16 & 33 & 49 & $P<0.01$ \\
\hline Don't know & 61 & 113 & 174 & \\
\hline
\end{tabular}

despite the tremendous increase of VCT services in Nigeria between 2002 and the present, ${ }^{21}$ the level of uptake of VCT services by members of the military has not changed. It is possible that the true rate is even lower than what has been documented due to possible multiple testing among this population.

It is possible that, overall, members of this group do not perceive themselves as a high-risk group in terms of HIV infection and therefore do not take any steps to determine their HIV serostatus. In the current study, only 52 (27.4\%) of the 190 military respondents perceived that members of the armed forces were a high-risk group for HIV infection. This finding is corroborated by other studies that assessed HIV risk perception among military men, where it has been found that $51.1 \%$ perceived no risk in Ilorin, ${ }^{15}$ and $40 \%$ perceived no risk in Lagos. ${ }^{14}$

One of the authors' research hypotheses was that members of the military in this cantonment, being part of a MARP group, would have a higher HIV testing behavior than the civilians. However, the findings showed no statistically significant difference in HIV testing between the military and 
the civilians $\left(\chi^{2}=2.607 ; P>0.05\right)$. It is probable that there was a nesting of persons with similar sexual risk behavior and HIV risk perception in this cantonment.

Age was one of the socio-demographic variables that influenced HIV testing in this study $\left(\chi^{2}=7.997 ; P<0.05\right)$. The 20-29 years age group had the highest rate of HIV testing (53.7\%) and a significantly higher proportion of this age group perceived members of the armed forces as a MARP group $\left(\chi^{2}=11.35 ; \mathrm{df}=3 ; P<0.005\right)$ (see Table 5). It is probable that this perception of higher risk influenced a higher HIV testing practice. Moreover, HIV epidemiology has continually shown a higher incidence in this age group than in other age groups in Nigeria, ${ }^{21}$ probably because people in the 20-29 years age group are usually more sexually active and indulge in higher-risk sexual behaviors. It is possible that this high-risk behavior also makes them perceive their high-risk status for acquiring HIV infection.

The most significant finding in this study was the relationship between awareness of VCT and receiving an HIV test $\left(\chi^{2}=81.843 ; P<0.001\right)$. This finding emphasizes the importance of continuous health education and community mobilization through all socially and culturally acceptable means to make as many people as possible aware that VCT services are available and to ensure they know where VCT centers are located. It is obvious that those who know that a service is available and where to access it are more likely to utilize the service.

Globally, the advent of and increasing access to ART has altered people's perception of and response to HIV/AIDS. ART has significantly reduced the utter hopelessness with which HIV/AIDS has been viewed in the past. The improvement in the quality of life associated with ART, ${ }^{22,23}$ especially when adherence can be assured, has influenced people's willingness to be tested. This could explain the significant finding in this study of an association between knowing that ART suppresses the virus, prolongs life, and increases the quality of life and receiving an HIV test $\left(\chi^{2}=9.116\right.$; $\left.\mathrm{df}=2 ; P<0.01\right)$.

It was an intriguing finding that in a highly literate urban population like the one studied (where $92 \%$ of the respondents had a secondary education or higher), as many as $54.3 \%$ of respondents would have a poor to very poor knowledge of VCT. This only emphasizes the fact that efforts must be made to target every group, no matter how highly educated or placed, in HIV/AIDS and VCT information dissemination efforts.

\section{Conclusion and recommendations}

The proportion of residents of the cantonment who had ever been tested for HIV was low. The factors that influenced whether or not an individual decided to be tested for HIV were (1) age; (2) education level; (3) marital status; (4) type of family; (5) awareness of VCT; (6) knowledge of ART (that is, that ART suppresses the replication of the virus, prolongs life, and improves the quality of life of PLWHAs); and (7) knowledge of where VCT services could be accessed.

It is recommended that high-risk population groups be targeted in HIV/AIDS and VCT information dissemination efforts. It is also recommended that free VCT services rendered in a confidential manner should urgently be established in the cantonment, in addition to provision of ART services for those who qualify for it, to enhance uptake of services. Other measures that would increase VCT uptake include (1) training and use of peer educators, especially those among the cantonment residents who have tested HIV positive; (2) training of senior military officers, senior members of the civilian population and the religious leaders in the cantonment as HIV counselors; (3) encouraging the religious leaders to include HIV/AIDS issues in their weekly sermons; and (4) implementing policies that will reduce stigmatization and discrimination against HIV-positive people.

\section{Acknowledgments}

The authors are grateful to the research assistants who helped with the data collection. The authors thank the cantonment commander for granting permission for this study to be performed in the cantonment. The authors especially thank the officer in charge of the MRS for her invaluable cooperation and assistance throughout the study.

\section{Disclosure}

The authors report no conflicts of interest in this work.

\section{References}

1. Commonwealth Regional Health Community Secretariat (CRHCS). HIV/ AIDS voluntary counselling and testing: review of policies, programmes and guidelines in east, central and southern Africa. Arusha, Tanzania: CRHCS; 2002:4

2. United Nations Population Fund (UNFPA). Integrating HIV voluntary counselling and testing services into reproductive health settings. London: International Planned Parenthood Federation and UNFPA; 2004.

3. World Health Organization (WHO). Rapid HIV test: guidelines for use in HIV testing and counselling services in resource-constrained settings. Geneva: WHO; 2004.

4. World Health Organization (WHO). Increasing access to HIV testing and counselling: report of a WHO consultation, November 19-21, 2002, Geneva, Switzerland. Geneva: WHO; 2002.

5. Joint United Nations Programme on HIV/AIDS (UNAIDS). Global HIV/ AIDS epidemic. Geneva: UNAIDS. Jul 2003. Available from: http://www. unaids.org/en/sub-saharanAfrica. Accessed February 19, 2008.

6. World Health Organization (WHO). Global HIV prevalence has leveled off [news release]. Geneva: WHO; 2007 Nov 20. 
7. United States Bureau of the Census, International Programs Center, Population Division. HIV/AIDS surveillance data. Washington DC: United States Bureau of the Census; 1998.

8. Sarin R. A new security threat: HIV and AIDS in the military. World Watch. 2003;16(2):17-22.

9. Adebajo SB, Mafeni J, Moreland S, Murray N. Armed Forces Programme on AIDS Control (AFPAC): Knowledge, Attitudes and Sexual Behaviour among the Nigerian Military Concerning HIV/AIDS and STDs; Final Technical Report. Abuja, Nigeria: Policy project; 2007.

10. Kingma, SJ. AIDS prevention, testing and care in current military practice. Int Conf AIDS. 1996;11:47. [Abstract Mo.D.350].

11. United Nations General Assembly Special Session (UNGASS) on AIDS. Nigeria UNGASS Report for 2005 [cited March 12, 2008]. Available from: http://data.unaids.org/pub/report/2006/2006_country_ progress_report_nigeria_en.pdf. Accessed October 4, 2011.

12. Matovu KB, Makumbi FE. Expanding access to voluntary HIV counselling and testing in sub-Saharan Africa: alternative approaches for improving uptakes, 2001-2007. Trop Med Int Health. 2007;12(11):1315-1322.

13. UNAIDS. Nigeria UNGASS Report for 2005: Preliminary Report. Geneva: UNAIDS; 2005. Avaliable at: http://data.unaids.org/pub/ report/2006/2006_country_progress_report_nigeria_en.pdf. Accessed August 29, 2011.

14. Adebajo SB, Mafeni J, Moreland S, Murray N. Armed Forces Programme on AIDS Control (AFPAC): knowledge, attitudes and sexual behaviour among the Nigerian military concerning HIV/AIDS and STDs; final technical report, Sep 2002. Abuja, Nigeria: Policy project; 2002.

15. Hussain NA, Akande TM, Olasupo ST. HIV/AIDS: an assessment of perception and predisposing factors among soldiers in Ilorin, Nigeria. J Community Med Prim Health Care. 2008;20(1):13-24.
16. Abimiku AG, Vertefeuille J, Villalba-Diebold P, et al. HIV knowledge, beliefs, and risk factors among soldiers in the Nigerian Military. Int conf AIDS. July 11-16, 2004;15: abstract no. ThPeC7531.

17. Centers for Disease Control and Prevention. QuickStats: percentage of adults aged $\geq 18$ years who reported ever being tested for human immunodeficiency virus (HIV), by sex and race/ethnicity; National Health Interview Survey, United States, 2006. MMWR Morb Mortal Wkly Rep. 2007;56(31):796. Available from: http://www.cdc.gov/mmwr/ preview/mmwrhtml/mm5631a5.htm?s_cid=mm5631a5_e. Accessed February 28, 2008.

18. Federal Ministry of Health (FMoH). National HIV/AIDS Reproductive Health Survey Plus (NARHS Plus, 2007). Abuja, Nigeria: FMoH; 2008: 49-84.

19. Okonkwo KC, Reich K, Alabi AI, Umeike N, Nachman SA. An evaluation of awareness, attitudes and beliefs of pregnant Nigerian women toward voluntary counseling and testing for HIV. AIDS Patient Care STDS. 2007;21(4):252-260

20. De Cock KM, Mbori-Ngacha D, Marum E. Shadow on the continent: public health and HIV/AIDS in Africa in the 21st century. Lancet. 2002;360(9326):67-72.

21. National Agency for the Control of AIDS (NACA). Progress towards universal access to HIV prevention, treatment, care and support. Abuja, Nigeria: NACA; 2008.

22. Phakathi Z, Van Rooyen H, Fritz K, Richter L. The influence of antiretroviral treatment on willingness to test: a qualitative study in rural KwaZulu-Natal, South Africa. Afr J AIDS Res. 2011;10(2):173-180.

23. Astoro NW, Ddjauzi S, Djoerban Z, Prodjosudjadi W. The quality of life of HIV patients and influential factors. Acta Med Indones. 2007;39(1):2-7.
HIV/AIDS - Research and Palliative Care

\section{Publish your work in this journal}

HIV/AIDS - Research and Palliative Care is an international, peerreviewed open-access journal focusing on advances in research in HIV, its clinical progression and management options including antiviral treatment, palliative care and public healthcare policies to control viral spread. The journal welcomes original research, basic science,

\section{Dovepress}

clinical \& epidemiological studies, reviews \& evaluations, expert opinion \& commentary, case reports \& extended reports. The manuscript management system is completely online and includes a very quick and fair peer-review system. Visit http://www.dovepress.com/ testimonials.php to read real quotes from published authors. 